\title{
Statistical optimization of arsenic removal from synthetic water by electrocoagulation system and its application with real arsenic polluted groundwater
}

\section{Claudia Erika Mendoza-Chávez, Anne Carabin, Ahmad Dirany, Patrick} Drogui, Gerardo Buelna, María Mercedes Meza-Montenegro, Ruth Gabriela Ulloa-Mercado, Lourdes Mariana Diaz-Tenorio, Luis Alonso Leyva-Soto \& Pablo Gortáres-Moroyoqui

To cite this article: Claudia Erika Mendoza-Chávez, Anne Carabin, Ahmad Dirany, Patrick Drogui, Gerardo Buelna, María Mercedes Meza-Montenegro, Ruth Gabriela Ulloa-Mercado, Lourdes Mariana Diaz-Tenorio, Luis Alonso Leyva-Soto \& Pablo Gortáres-Moroyoqui (2020): Statistical optimization of arsenic removal from synthetic water by electrocoagulation system and its application with real arsenic polluted groundwater, Environmental Technology, DOI: 10.1080/09593330.2020.1732472

To link to this article: https://doi.org/10.1080/09593330.2020.1732472

Accepted author version posted online: 19 Feb 2020.

Submit your article to this journal $\widetilde{ }$

Q View related articles $\sqsubset$

View Crossmark data $\nearrow$ 
Publisher: Taylor \& Francis \& Informa UK Limited, trading as Taylor \& Francis Group

Journal: Environmental Technology

DOI: $10.1080 / 09593330.2020 .1732472$

Check for updates

Statistical optimization of arsenic removal from synthetic water by electrocoagulation system and its application with real arsenic polluted groundwater

Claudia Erika Mendoza-Chávez ${ }^{a}$, Anne Carabin ${ }^{b}$, Ahmad Diranyb, Patrick Drogui $^{\mathrm{b}}$, Gerardo Buelna ${ }^{\mathrm{b}}$, María Mercedes Meza-Montenegro ${ }^{\mathrm{a}}$, Ruth Gabriela Ulloa-Mercado ${ }^{\text {, }}$, Lourdes Mariana Diaz-Tenorio ${ }^{a}$, Luis Alonso Leyva-Soto ${ }^{\text {a }}$, Pablo Gortáres-Moroyoqui ${ }^{a *}$.

${ }^{a}$ Departamento de Biotecnología y Ciencias Alimentarias, Instituto

Tecnológico de Sonora (Centro de Investigación e Innovación

Biotecnológica, agropecuaria y ambiental), 5 de febrero 818 sur, Ciudad Obregón, Sonora, México. Phone: (644) 4100900.

${ }^{b}$ Institut national de la recherche scientifique-Centre Eau, Terre et Environnement (INRS-ETE), Université du Québec, 490 rue de la Couronne, Québec, QC, Canada, G1K 9A9. Phone: +1 (418) 654-2530, Fax: +1 (418) 654-2600.

Corresponding Author;pablo.gortares@itson.edu.mx 


\section{Statistical optimization of arsenic removal from synthetic water by electrocoagulation system and its application with real arsenic polluted groundwater}

Abstract

Arsenic presence in water has become one of the most concerning environmental problems. Electrocoagulation is a technology that offers several advantages over conventional treatments such as chemical coagulation. In the present work, an electrocoagulation system was optimized for arsenic removal at initial concentrations of $100 \mu \mathrm{g} / \mathrm{L}$ using response surface methodology. The effects of studied parameters were determined by a 23 factorial design; whereas treatment time had a positive effect and current intensity had negative effect on arsenic removal efficiency. With a p-value 0.1629 and a confidence level $99 \%$, the type of electrode material did not have significant effect on arsenic removal. Efficiency over 90\% was reached at optimal operating conditions of 0.2 A of current intensity, and 7 min of treatment time using iron as the electrode material. However, the time necessary to accomplish with OMS arsenic guideline 10 $\mu \mathrm{g} / \mathrm{L}$ increased from 7 to 30 minutes when real arsenic contaminated-groundwater with an initial concentration of $80.2 \pm 3.24 \mu \mathrm{g} / \mathrm{L}$ was used. The de of a pilot-scale electrocoagulation reactor was determined with the capacity to meet the water requirement of a 6417 population community in Sonora, Mexico. To provide the $1.0 \mathrm{~L} / \mathrm{s}$ required, an electrocoagulation reactor with a working volume of $1.79 \mathrm{~m} 3$, a total electrode effective surface of $701 \mathrm{~m} 2$, operating at a current intensity of $180 \mathrm{~A}$ and an operating cost of $0.0208 \mathrm{US} \$ /$ day was proposed. Based on these results, electrocoagulation can be considered an efficient technology to treat arseniccontaminated water and meet the drinking water quality standards. 


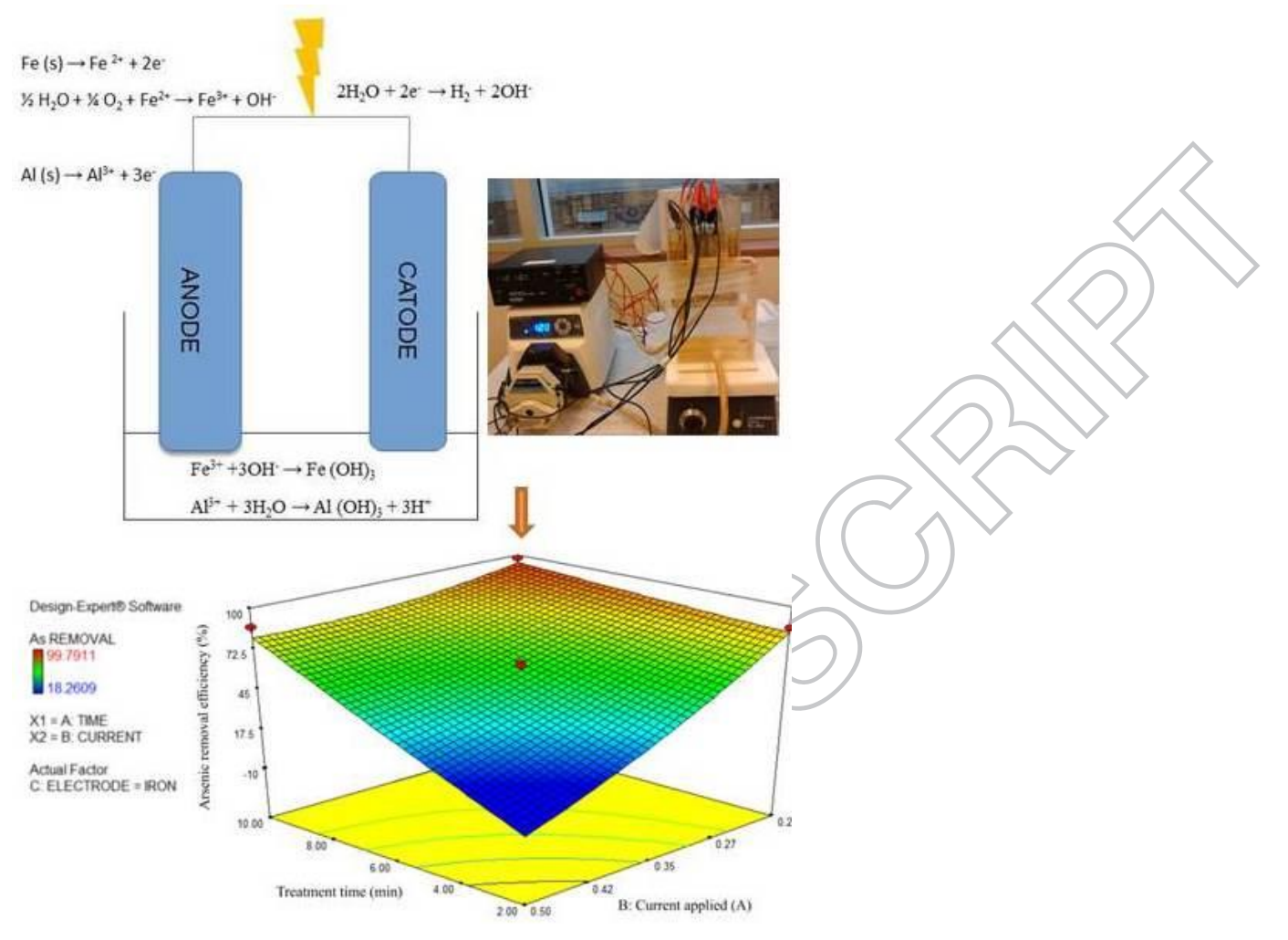

Keywords: electrocoagulation; response surface methodology; arsenic contaminated water; real groundwater; optimization.

\section{Introduction.}

Water is a very important resource for life and human activities, such as industry, agriculture, mines, domestic, and others. However, natural water resources bodies are contaminated with inorganic and organic compounds, which coming to wastewater from different anthropogenic activities (Ali et al 2013; Ali et al, 2019). According to Basher $(2018,2018 b)$ and Basheer and Ali (2019) many of the pollutants discharged to natural water resources present a low uptake and degradation due to chirality. Some of these pollutants are pesticides, polychloro biphenyls, polyaromatic hydrocarbons, brominated flame retardants, drugs, and pharmaceuticals. Therefore, the removal of pollutants in water is critical and important before to supplying it to the community. 
Arsenic in drinking water has become one of the most concerning environmental problems, due to its toxicity and wide distribution. Although arsenic is present in the environment under natural conditions, uncontrolled anthropogenic activities and the discharge of untreated wastewater, increase its mobilization, contaminating drinking water sources (Choong et al., 2007; Gorny et. al., 2015; Sabbatini et al., 2010).

Arsenic in water can be present as organic and inorganic forms, being this later more toxic and mobile than the first (Izah et. al., 2015; Kaur et. al., 2015; Vaclavikoya et al., 2008). Predominant inorganic forms in natural waters are arsenite (IH); found under reducing conditions, and arsenate $(\mathrm{V})$; in more oxidized environments (Ali et. al., 2011; Baig et. al., 2015; Jadhav et. al., 2015; Nidheesh et. al., 2017).

According to the world health organization (2011), the main route of arsenic exposure is the intake of polluted water. Affectations of the gastrointestinal tract, hyperkeratosis, skin lesions, cardiac, vascular and nervous systems are some of the arsenic effects, and it is considered as a carcinogen (Ali \& Asim, 2013; Basu et. al. 2014; Kaur et. al., 2015; Wan et. al., 2011).

It has been estimated that over 100 millions of people globally are at risk of arsenic exposure due to contaminated water in more than 70 countries (Ali et al., 2011; Ali \& AlOthman, 2014; Jadhav et. al., 2015). Some of the most affected regions with arsenic in water are extended areas in Bangladesh and India; as well as Argentina, where concentrations were found up to $11500 \mathrm{ppb}$ (Bhattacharya et al., 2007; Choong et al., 2007; George et. al., 2017; Sabbatini et al., 2010). In Mexico, contaminated arsenic water has been reported in concentrations up to $305 \mathrm{ppb}$, in the northwest region in Hermosillo 
city; as well as different concentrations in villages like Etchojoa, Vicam, and Potam (Meza et al., 2004).

In order to reduce arsenic exposure, the world health organization (WHO) has lowered the arsenic maximum contaminant level in water to $10 \mathrm{ppb}$ (Jadhav et. al., 2015; Li et. al., 2014). In order to meet the new WHO regulation, a development of new technologies would be required. Some of these technologies include filtration and adsorption processes, conventional chemical coagulation and electrochemical systems. Although high arsenic removal efficiencies can be achieved by some membrane technologies, membrane cost and fouling over time is still a concern. Some low cost membrane materials with high arsenic removal efficiency have been developed but although they have shown not to be $\mathrm{pH}$ dependent, presented some fouling for As (V) removal at neutral $\mathrm{pH}$ values in some tests (Hubadilla et. al., 2019). Adsorption-ultrafiltration combined process with high arsenic removal efficiencies have also shown reduced performance after long operation times due to membrane fouling and adsorbent exhaustion when water with high content of suspended solids was used (Hao et. al., 2018). This is a concern since natural groundwater may have complex compositions and normally $\mathrm{pH}$ values between 6 and 9 (Sik et. al., 2017). Due to practicality, coagulation and flocculation processes are the most common technology used for arsenic removal from water but present the disadvantage of producing large amounts of contaminated sludge (Del-Angel et. al., 2014; Choong et. al., 2007).

Electrocoagulation is an electrochemical technique alternative to chemical coagulation that delivers coagulant in situ caused by anode dissolution (oxidation) as a consequence of the direct applied current (Asselin et al., 2008; Moussa et. al., 2017; Nidheesh et. al., 
2017; Oncel et. al., 2013). When anode oxidation occurs, metal cations are released into the solution, forming metal hydroxides with the hydroxyl ions produced at cathode's surface that precipitate with absorbed pollutants at appropriated $\mathrm{pH}$ values (Flores et. al., 2013; Oncel et. al., 2013). As result of cathode reduction, hydrogen gas is also produced creating a flotation process (Mohora et al., 2014; Moussa et. al., 2017). Diagram of electrocoagulation process is shown in figure 1.

The most used sacrificial electrode material in electrocoagulation for arsenic removal is aluminum and iron, due to their low cost and high efficiency (Flores et. al., 2013). Arsenic removal reactions when iron and aluminum are used as electrodes are presented in equations 1 and 2, respectively (Balasubramanian et al., 2009; Ali et al., 2012):

$$
\begin{aligned}
& \mathrm{Fe}(\mathrm{OH})_{3}(\mathrm{~s})+\mathrm{AsO}_{4}{ }^{3-}(\mathrm{aq}) \rightarrow\left[\mathrm{Fe}(\mathrm{OH})_{3} * \mathrm{AsO}_{4}{ }^{3-}\right](\mathrm{s}) \\
& \mathrm{Al}(\mathrm{OH})_{3}(\mathrm{~s})+\mathrm{AsO}_{3}{ }^{4-}(\mathrm{aq}) \rightarrow\left[\mathrm{Al}(\mathrm{OH})_{3} * \mathrm{AsO}_{3}{ }^{4}\right](\mathrm{s})
\end{aligned}
$$

EC offers an advantage for small communities since it produces less sludge, does not require to handle chemicals, floes formed can be readily separated by filtration due to its good stability, flotation process takes place and facilitates the pollutants removal, produces clear, odorless and colorless water and it is easy to operate and to maintain with locally available materials (Li et. al., 2014; Mohora et. al., 2014; Moussa et. al., 2017). Despite a large number of studies that have been carried out about arsenic removal efficiency through electrocoagulation, it still has some limitations working at large scale (Ali \& Gupta, 2012). Besides, optimal conditions for operational parameters such as applied current intensity, treatment time and type of electrode material are not fully known due to the difference in water chemistry. For current applied, most of the works showed a higher arsenic removal efficiency when the current intensity applied is 
increased (Can et. al., 2014; García et. al., 2014; Kumar et. al., 2004; Martinez-Villafañe et. al., 2009). However, electrical consumption may be increased significantly higher compared to removal efficiency (Can et. al., 2014). Another problem related to the use of higher current intensities is the anode passivation, which decreases the arsenic removal efficiency (Flores et. al., 2013). Treatment time has been found dependent to applied current intensity (Martinez-Villafañe et. al., 2009); due to its direct relation to iron dissolution expressed in Faraday's law (Li et. al., 2014; Martinez-Villafañe et. al., 2009). In a work carried out by Ali et. al. (2012), arsenic in a concentration of $2 \mathrm{mg} / \mathrm{L}$ was removed almost completely at 10 minutes using a potential of $3 \mathrm{~V}$ with no significant improvement found after this treatment time. Nonetheless, treatment time required to remove arsenic completely may be increased when water composition is changed (Garcia-Lara et. al., 2010).

In order to identify the optimal operating conditions in terms of current intensity, treatment time and type of electrode material, response surface methodology may be used. Response surface methodology (RSM) is a statistical and mathematical technique for designing experiments that allow building models, evaluating the effects of several variables or factors, and optimizing processes in which a response variable is influenced by several independent variables (Bas et al., 2007; Wang et. al., 2007). Some authors have used RSM to optimize the arsenic removal through electrocoagulation systems (Garcia-Lara et. al., 2014; Kobya et. al., 2013); however, no clear optimal operational conditions for some parameters like treatment time, current intensity, and type of electrode material have been reported since are strongly dependent on specific water composition. 
The aim of the present research work is to determine the optimal operating conditions in a bench-scale electrocoagulation system for arsenic removal from synthetic water and to identify the effect of the applied current intensity, type of electrode material and treatment time on arsenic removal efficiency using response surface methodology. As novelty, arsenic removal efficiency in real arsenic-polluted groundwater at optimal operating conditions was also evaluated and the design of a pilot-scale electrocoagulation reactor to meet the water demand of a community of the Sonora's northwest was determined.

\section{Materials and methods}

\subsection{Preparation of As synthetic solution}

Arsenic synthetic stock solution with a concentration of $100 \mathrm{mg}$ of As/L was prepared with $\mathrm{Na}_{2} \mathrm{HAsO}_{4} \cdot 7 \mathrm{H}_{2} \mathrm{O}$ high purity of $98 \%$ (CAS \# 15120-17-9). Influent for electrocoagulation reactor of $100 \mu \mathrm{g}$ of As/L was prepared before each test by adding the required volume of arsenic stock solution and distilled water into a $2 \mathrm{~L}$ volumetric flask. Sodium sulfate $\left(\mathrm{NaSO}_{4}\right.$, CAS \# 7757-82-6) was added to the influent solution as electrolyte. All chemicals were provided by Sigma-Aldrich and used as received without any purification.

\subsection{Experimental unit.}

Experimental unit consisted of a bench-scale electrocoagulation reactor $(13.6 \mathrm{~cm} \mathrm{x} 13 \mathrm{~cm}$ x21 cm) made of acrylic with a working volume of $1.7 \mathrm{~L}$. Effluent was recirculated with a peristaltic pump at a constant flow rate of $120 \mathrm{~mL} / \mathrm{s}$. In order to avoid flocs 
sedimentation, effluent was agitated with a Teflon-covered magnetic stirrer bar in the collector before being recirculated. Picture of the bench-scale electrocoagulation system used is shown in figure 2.

Electrodes were connected to a DC power supply (EXTECH, $230 \mathrm{~V}$, and $600 \mathrm{~W}$ ) in monopolar arrangement (four anodes and four cathodes) with an inter-electrode space of $1 \mathrm{~cm}$. The size of the electrodes was $11 \times 10 \mathrm{~cm}$ with a thickness of $1 \mathrm{~mm}$ for cathode and $2 \mathrm{~mm}$ for anode; an effective surface of $80 \mathrm{~cm}^{2}$ each, and a total effective surface for the four electrodes of $56 \mathrm{~cm}^{2}$. Electrode material was stainless steel for cathode, and aluminum or iron for anode as the case.

\subsection{Experimental design.}

Response surface methodology was applied to optimize electrocoagulation system using software design expert 7. This methodology consisted of a $2^{3}$ factorial design carried out to determine the effect of operational variables over the response, followed by a central composite design of 26 experiments generated by the software to determine optimal operating conditions. Variables or factors studied were: treatment time $\left(\mathrm{X}_{1}\right)$, and current intensity (X2), and electrode type $\left(\mathrm{X}_{3}\right)$; level values for each variable are shown in table 1. After optimal operating conditions were obtained, experiments were carried out at these conditions to confirm the accuracy of the model to predict the arsenic removal

\section{efficiency.}

\subsection{Experimental procedure}

All experiments were carried out using synthetic water with a constant arsenic concentration $100 \mu \mathrm{g} / \mathrm{L}$, same reactor configuration and monopolar electrode 
arrangement was used for all tests. After the treatment, effluent was allowed to settle for $1 \mathrm{~h}$ to collect $50 \mathrm{ml}$ of supernatant liquid for arsenic, $\mathrm{pH}$ and conductivity analysis. All samples were filtered, under vacuum, with a glass fiber filter Whatman (Cat. No. 1822042) and it was stored at $4^{\circ} \mathrm{C}$ until analysis.

\subsection{Analytical techniques.}

In experiments with synthetic water, arsenic concentration was determined by inductively coupled plasma mass spectrometry (ICP-MS), with a limit of arsenic detection of 0.014 ppb. Before arsenic analysis by ICP-MS, the samples were preserved at $0.2 \%$ with nitric acid and stored at $4{ }^{\circ} \mathrm{C}$.

For the experiments with real groundwater, arsenic concentration was measured by atomic absorption spectroscopy with vapor generation assembly (VGA), with a limit of detection of $3 \mathrm{ppb}$. Before analysis, samples were prepared with potassium iodide and chlorhydric acid according to official methodology (APHA, 1992). In all experiments, $\mathrm{pH}$ and conductivity were measured with a pH-meter (Fisher Acumet model 915) and with a conductivity meter (Oakton Model 510), respectively.

During electrocoagulation experiments with real groundwater, molybdate reactive silica concentration was also determined before and after treatment in order to evaluate its removal and thus its effect on arsenic removal efficiency.

\subsection{Real groundwater electrocoagulation experiments.}

In order to evaluate arsenic removal efficiency of the electrocoagulation system with real groundwater, experiments with groundwater from a small community with arsenic contamination were carried out. Samples were collected from a well that supplies water to the village of Potam, a rural 6417 population (SEDESOL, 2013) community part of the 
Yaqui Valley region in Sonora State, northwest of Mexico. Arsenic initial concentration in real groundwater was $80.2 \pm 3.24 \mu \mathrm{g} / \mathrm{L}$, initial $\mathrm{pH} 8.4$ and a conductivity of 1746 $\mu \mathrm{S} / \mathrm{cm}$. Samples were collected and stored in polypropylene bottles, kept at $4^{\circ} \mathrm{C}$ until use. Experiments with real groundwater were performed with the same experimental procedure and at optimal operating conditions. Theoretical iron dose produced and different charge loading used were calculated based on current applied and treatment time, according to Faraday's law (Li et. al., 2014); and current intensity, treatment time and reactor volume respectively according to references (Amrose et. al, 2013).

\section{Results and discussion.}

\subsection{Factorial design}

Experiments with arsenic synthetic water were carried out at different operational conditions in order to determine levels for a factorial design. These experiments were performed with aluminum and iron as anode material; $0.1,0.2$ and $0.5 \mathrm{~A}$ of current intensity; and treatment times of 2,5 and 10 minutes. Under these experimental conditions, the highest arsenic removal efficiency obtained was above $99 \%$, using $0.1 \mathrm{~A}$ of current intensity, and iron as anode material for 2 minutes of treatment. The lowest arsenic remoyal efficiencies obtained were around $18 \%$ with aluminum as anode material at treatment times of 2 and 5 minutes.

Based on these results, levels chosen were 0.2 and $0.5 \mathrm{~A}$ for current intensity; 2 and 5 minutes for treatment time; and aluminum and iron as anode material (Complete factorial plan design and experimental results are shown in table 2). Effects of operational 
parameters on the arsenic removal efficiency were evaluated using Pareto chart presented in figure 3.

Treatment time was the variable that had the most significant effect on arsenic removal efficiency, presenting a positive effect (figure3). This it is agree with previous works using electrocoagulation systems (Kobya et. al., 2013) and could be due to the timedepending flocs formation according to Faraday's law (Li et. al., 2014; MartinezVillafañe et. al., 2009).

Current intensity showed a negative effect on arsenic removal, contrasting with previous works with electrocoagulation (Demirbas et. al., 2018; Sik et. al., 2017; Garcia-Lara et. al., 2014). Moreover, applied current intensity determines coagulant dose, bubble, and sludge production, which tend to increase arsenic removal efficiency (Zhao et. al., 2010). However, in previous work carried out by Flores et. al. (2013), it was found no further improvement on arsenic removal efficiency when increasing the current applied beyond 0.4 A. This negative effect was attributed to the possible anode passivation and excessive gas generation product of water hydrolysis, which could also have affected the removal efficiency on present work. This is important for electrocoagulation systems since the use of a low current intensity is desired to reduce the operating cost. Also, the ratio of of arsenic remoyed per Iron produced is reduced as current intensity and treatment time is increased (Demirbas et. al., 2018).

In this research work, with a p-value of 0.1629 , the type of electrode material did not show a significant effect on arsenic removal efficiency. Nevertheless, the addition of more electrolytes was required to keep current constant when using aluminum electrode, probably due to anode passivation. Also, aluminum concentration in water after the 
treatment is a cause of concern because of its toxicity, associated with neurological diseases (Campbell et al., 2004). Thus, iron was considered the best anode material. A first-order equation obtained in terms of coded factors is shown in equation 3 , where only the following factors showed a significant effect on arsenic removal (Asrem) and thus only considered: treatment time $\left(\mathrm{X}_{1}\right)$, current intensity $\left(\mathrm{X}_{2}\right)$, alone and their coupled effect, as well as the combined triple effect of type of electrode material $\left(\mathrm{X}_{3}\right), \mathrm{X}_{2}$, and $\mathrm{X}_{3}$. The accuracy of this model was evaluated using ANOVA analysis for factorial design. The $\mathrm{R}^{2}$ value obtained was 0.99 and it was consistent with $A d j \mathrm{R}^{2}$ (adjusted $\mathrm{R}^{2}$ ) and Pred $\mathrm{R}^{2}$ (predicted $\mathrm{R}^{2}$ ) with values of 0.99 both; standard deviation and variation coefficient were 0.97 and $1.25 \%$, respectively. Adeq precision (adequate precision) obtained was 87.52 , indicating an adequate signal and that values of the response are not due to data's noise. Based on statistical analysis, this model showed a relevant accuracy. Moreover, with a $p$-value of 0.0226 , the model may be considered as significant.

$\mathrm{As}_{\mathrm{rem}}=77.97+17.11 \mathrm{X}_{1}-16.55 \mathrm{X}_{2}+2.90 \mathrm{X}_{1} \mathrm{X}_{3}-3.08 \mathrm{X}_{1} \mathrm{X}_{3}+13.94 \mathrm{X}_{1} \mathrm{X}_{2}+5.78 \mathrm{X}_{1} \mathrm{X}_{2} \mathrm{X}_{3}$

\subsection{Central composite design}

After identifying parameter's effects on arsenic removal efficiency, a central composite design was carried out following the same experimental procedure than factorial design. Complete experimental matrix and response variables of central composite design are shown in table 3 . The highest arsenic removal efficiency was $99.79 \%$ using iron as anode material, $0.14 \mathrm{~A}$ of current intensity and treatment time of 6 minutes. The lowest efficiency of $18.26 \%$ was the same obtained with $0.5 \mathrm{~A}$ of current intensity, using 
aluminum as anode material and treatment time of 2 minutes during factorial design experiments.

Based on results from central composite design, a second order equation expressing arsenic (Asrem) efficiency in function of current intensity applied, treatment time and type of electrode material was determined as follows:

$$
\mathrm{AS}_{\mathrm{rem}}=61.92+23.22 \mathrm{X}_{1}-20.19 \mathrm{X}_{2}+3.51 \mathrm{X}_{3}+17.22 \mathrm{X}_{1} \mathrm{X}_{2}+4.25 \mathrm{X}_{2} \mathrm{X}_{3}+0.61 \mathrm{X}_{1}^{2}+
$$

\section{$5.44 \mathrm{X}_{2}^{2}$}

Where, $\mathrm{X}_{1}, \mathrm{X}_{2}$, and $\mathrm{X}_{3}$ represent treatment time, current intensity and type of electrode material respectively; $\mathrm{X}_{1} \mathrm{X}_{2}$ and $\mathrm{X}_{2} \mathrm{X}_{3}$ the of combined effect of factors.

The $\mathrm{R}^{2}$ (.956) value for this model was consistent to Adj $\mathrm{R}^{2}$ and Pred $\mathrm{R}^{2}(0.93$ and 0.89, respectively); while the Adeq precision obtained was 25.366 . Figure 4 shows the plot of predicted response variable versus the actual, with a tendency to linearity, it indicates an appropriate accuracy and thus, the model can be used for optimization.

Criteria chosen to obtain the optimal operating conditions were to maximize arsenic removal efficiency, as the main goal, followed by to minimize treatment time and current intensity applied. Limits set for arsenic removal efficiency were 80 and $99 \%$ as lowest and highest, respectively, range of treatment time desired of 2 to 10 minutes and current intensity range of 0.2 to $0.5 \mathrm{~A}$.

After evaluating experimental conditions suggested by design expert, $0.2 \mathrm{~A}, 7$ minutes and iron as anode material were chosen as the optimal operation conditions due to its high arsenic removal efficiency (90\%) that will result in a final concentration of $10 \mu \mathrm{g} / \mathrm{L}$. Indeed, these experimental conditions enable to meet Mexican regulation $(25 \mu \mathrm{g}$ of As/L according to NOM-127-SSA1-1994) and WHO's guideline for arsenic (10 $\mu \mathrm{g}$ of As/L) 
with a low current intensity and within the shortest treatment time. Figure 5 shows the response surface plot for arsenic removal efficiency in function of current intensity, treatment time and type of electrode material.

In order to confirm the predicted response accuracy, experiments were carried out at optimal operating conditions. Arsenic removal efficiencies obtained under these conditions were $92.2 \pm 1.3 \%$, slightly above the value predicted by the software of $90 \%$ with a deviation of 1.1. Considering these results, the accuracy of the model was confirmed and the WHO's guidelines for arsenic in water was achieved.

\subsection{Application of the optimized electrocoagulation system on real arsenic-}

\section{contaminated groundwater.}

Experiments with real groundwater (characteristics previously described) were carried out at optimal operating conditions of $0.2 \mathrm{~A}, 7$ minutes of treatment time, and iron as the type of electrode material.

Under these conditions, after 7 minutes of treatment, the residual arsenic concentration was $50.9 \pm 5.2 \mu \mathrm{g} / \mathrm{L}$, which is only an arsenic removal efficiency of $36.4 \%$. Compared to experiments with synthetic water, arsenic removal efficiency decreased from 92.2 to 39.6 $\%$ when real groundwater was used. In order to reach a higher arsenic removal and meet the Mexican and WHO's guidelines, experiments were performed using longer treatment times. Figure 6 shows the arsenic residual concentration against time in experiments with real groundwater. As seen in figure 6, arsenic concentration remained almost constant between 7 and 15 minutes, with a reduction of only $2.38 \mu \mathrm{g}$ of As/L in double time.

However, after 30 minutes of treatment, arsenic removal efficiency was $85.22 \%$, leading to a residual concentration of $11.86 \pm 0.6 \mu \mathrm{g}$ of As/L. This latter arsenic residual 
concentration meet the Mexican regulation but slightly exceeded WHO's guideline for arsenic in water of $10 \mu \mathrm{g} / \mathrm{L}$.

For a better understanding of arsenic removal's behavior in the electrocoagulation system, arsenic removal rate when using real groundwater was determined and compared to the one obtained with synthetic water, according to their respective zero order equation (figure 7 and 8, respectively). As seen in figure 7 and 8, arsenic removal rate decreased from 6.65 to $2.1189 \mu \mathrm{g} / \mathrm{L} \cdot \mathrm{min}$ when real groundwater was used.

Arsenic removal rate's behavior may be expected since dissolved species, such as silica and phosphate, present in groundwater affect arsenic removal efficiency due to competence for ferric oxyhydroxides adsorption sites (Garcia-Lara et. al., 2010; Lakshmanan et al., 2010; Wan et. al., 2011). At these operating conditions, no significant silica removal was detected through electrocoagulation system (data not shown). Consequently, silica negative effect on arsenic removal efficiency could not be proven; and thus, decrease in arsenic removal rate may be attributed to dissolved compounds present in groundwater not analyzed. Ions such as phosphate $\left(\mathrm{PO}_{4}{ }^{3-}\right)$ have shown to reduce arsenic removal in concentrations of $1 \mathrm{mg} / \mathrm{L}$ using electrocoagulation systems (Wan et. al.,2011). Also, it has shown to be the ion with greater effect when compare to sodium, potassium, calcium, magnesium, chloride, nitrate, and sulphate ions on arsenic adsorption (Ali \& Al-Othman, 2014). However, additional experiments should be performed to evaluate the presence of phosphate in Potam's groundwater and its effect on arsenic removal.

High $\mathrm{pH}$ of 8.46 of real groundwater could also have affected arsenic removal efficiency as it's been found by other authors higher efficiencies at lower initial $\mathrm{pH}$ values (5.4) 
(Mohora et. al., 2014; Wan et. al. 2011). Lower arsenic removal has also been found at higher $\mathrm{pH}$ values in other adsorption based processes (Hao et. al., 2018). This can be attributed to the isoelectric point of formed lepidocrocite $(\gamma-\mathrm{FeOOH})$ reported at $\mathrm{pH}$ of 7 , with a negatively charged surface above this value that is less favorable for arsenic adsorption (Ali et al., 2012; Wan et. al, 2011). Below this $\mathrm{pH}$ value, $\gamma$-FeOOH is positively charged, which facilitates the arsenate removal (Ali et. al., 2012). Optimum $\mathrm{pH}$ range reported for arsenic and antimony removal through electrocoagulation was 5-7 (Song et. al., 2014), but this range differs among authors since competing anions affect optimal pH (Sahu et. al., 2014). Another factor that decreases the arsenic removal efficiency is arsenic speciation, since arsenic (III), neutrally charged at $\mathrm{pH}$ range of $4-10$ needs to be first oxidized to As (V) to be removed, decreasing arsenic removal rate (Can et. al., 2014; Jadhav et. al., 2015; Camacho et. al., 2011; Wan et. al., 2011). However, in a characterization previously reported by Maldonado et. al. (2018) of Potam's groundwater, only arsenic (V) was found. For this reason, the decrease in arsenic removal rate could be attributed to the presence of phosphate or other compounds not analyzed and a high initial $\mathrm{pH}$ value as previously explained.

Theoreticaliron dose produced and different charge loading used during experiments with real groundwater were determined. Table 4 shows arsenic residual concentrations obtained at the different charge loading and its theoretical iron dose for experiments with real groundwater. As can be seen in the values of table 4, the arsenic residual concentration was inversely proportional to charge loading due to increase in the theoretical iron dose. However, at charge loading range of 43.74 to $90 \mathrm{C} / \mathrm{L}$, there was not 
significant reduction in arsenic concentration, which corresponds to the decrease in arsenic removal rate attributed to dissolved constituents in groundwater and previously discussed. Only after $180 \mathrm{C} / \mathrm{L}$ of charge dose was applied and theoretically $51.76 \mathrm{mg}$ of iron $/ \mathrm{L}$ was produced, arsenic concentration was lowered to $11.86 \pm 0.6 \mu \mathrm{g} / \mathrm{L}$. Compared to a synthetic solution experiments, where arsenic concentrations dropped to $2.5 \pm 2.5$ $\mu \mathrm{g} / \mathrm{L}$ when only $43.47 \mathrm{C} / \mathrm{L}$ was applied and $12.58 \mathrm{mg}$ of $\mathrm{Fe} / \mathrm{L}$ was theoretically produced, can be assumed that due to the complex groundwater matrix more iron oxide hydroxide was required and consequently more charge loading was also needed to efficiently remove arsenic. In previous work with electrocoagulation (Amrose et. al., 2013), an arsenic concentration of $90 \mu \mathrm{g} / \mathrm{L}$ was removed to accomplished the WHO's MCL (10 $\mu \mathrm{g} / \mathrm{L}$ ) with only $70 \mathrm{C} / \mathrm{L}$. However, differences in water matrix between this study and the present work could be the reason for the different charge loading required. Using iron ball electrodes, $3.553 \mu \mathrm{g}$ of As per mg of iron was removed by an electrocoagulation system using real groundwater by Sik et al (2017). Calculating the amount of arsenic removed per mg of iron from yalues in table 4 , only $1.31 \mu \mathrm{g}$ of As was removed per mg of iron when real groundwater was used. The reason for the lower removal obtained in this research work compared to their study may be aeration system used in their system that improved the oxidation of $\mathrm{Fe} 2+$ to $\mathrm{Fe} 3+$. However, in experiments with synthetic arsenic solution in our system when no additional compounds were present, a value of $7.75 \mu \mathrm{g}$ of As/mg of iron was removed. Thus the system can be considered efficient for arsenic removal and its efficiency when other compounds such as phosphate (as previously explained) are present may be increased by increasing the oxidation rate of $\mathrm{Fe} 2+$ to $\mathrm{Fe} 3+$. This can be done by improving the mixing or increasing the treatment time as in the 
experiments carried out for $30 \mathrm{~min}$, when the arsenic concentration was successfully decreased to meet Mexican guidelines.

Groundwater conductivity of $1746 \mu \mathrm{S}$ remained constant after treatment, showing the same behavior than experiments with synthetic water. Moreover, $\mathrm{pH}$ value of 8.4 did not significantly increase after treatment, in contrast with optimization experiments with synthetic water, where $\mathrm{pH}$ was increased from 5.4 to $7-8$. Nonetheless, precipitated were observed on the filter after filtration, indicating that iron hydroxides were formed. The $\mathrm{pH}$ value obtained after treatment coincides with previous work with real groundwater, where $\mathrm{pH}$ almost constant after treatment was reported (Garcia-Lara et. al., 2010). Based on the optimal operating conditions determined, a pilot scale electrocoagulation reactor design was proposed. This electrocoagulation reactor was designed to operate at a flow rate of $0.999 \mathrm{~L} / \mathrm{s}$, minimum required to meet the drinking water demand for the village of Potam. For this flow rate to be constant, with a hydraulic retention time of 30 minutes necessary to reach Mexican guideline for arsenic determined in experiments with real groundwater, a $1.798 \mathrm{~m}^{3} /$ reactor would be required. This volume was determined by the equation $\mathrm{V}=\mathrm{Q}^{*} \mathrm{HRT}$, where $\mathrm{V}$ is reactor volume, $\mathrm{Q}$ is flowrate and $\mathrm{HRT}$ hydraulic retention time Electrode effective surface per volume of water ratio $(\mathrm{S} / \mathrm{V})$ was another parameter used for scaling. With an S/V ratio of 0.39 as used in bench scale experiments and appropriated according to bibliography (Hansen et. al., 2007), a total electrode effective surface of $701.56 \mathrm{~m}^{2}$ would be required. Due to reactor dimensions, this effective surface may be supplied by 40 electrodes $(76 \times 116 \mathrm{~cm})$. Current density determined in bench scale experiments will be kept constant to $0.000256 \mathrm{~A} / \mathrm{cm}^{2}$. For this current density and the electrode effective surface determined, a current intensity of 179.6 
A would be necessary. Operation cost was calculated at these operating conditions based on electrical consumption obtained in bench scale experiments, according to the equation $\mathrm{P}=\mathrm{V}^{*} \mathrm{I}$; where $\mathrm{P}$ is equal to power, $\mathrm{V}$ to voltage, and $\mathrm{I}$ to current. Considering the Mexican electricity fees, estimated operating cost was USD $\$ 0.0208 / \mathrm{m}^{3}$, slightly lower than obtained by other works with electrocoagulation systems (Demirbas \& Kobya, 2017); and lower than estimated cost for chemical coagulation (Mólgora et. al., 2013) although electricity fees vary between countries.

\subsection{Arsenic removal mechanism through electrocoagulation.}

Regarding the arsenic removal mechanism through electrocoagulation, according to Wan et. al. (2011), and as previously discussed, at $\mathrm{pH}$ values higher than 7.3 the iron hydroxide formed has a negative surface charge which disadvantages the adsorption of anionic arsenate to them. Since the $\mathrm{pH}$ of the experiments with real groundwater at optimal conditions was 8.43 , it is suggested that the main arsenic removal mechanism may be the precipitation and co precipitation of soluble arsenate with iron according to equation 5 and 6 , for $\mathrm{Fe}^{2+}$ and $\mathrm{Fe}^{3+}$ respectively (Pallier, 2008). Thus, the precipitated arsenic was removed in form of sludge after settling stage.

$$
\begin{aligned}
& 3 \mathrm{Fe}^{2+}+2 \mathrm{AsO}_{4}^{3-} \rightarrow \mathrm{Fe}_{3}\left(\mathrm{AsO}_{4}\right)_{2} \\
& \mathrm{Fe}^{3+}+\mathrm{AsO}_{4}{ }^{3-} \rightarrow \mathrm{FeAsO}_{4}
\end{aligned}
$$

Equation 5

Equation

For experiments of optimization with a synthetic solution, $\mathrm{pH}$ value (5.2) was lower than the isoelectric $\mathrm{pH}$ of 7 previously mentioned, where the particle surface is expected to be 
positively charged. For this reason, adsorption at the surface of the iron oxide hydroxide flocs and charge neutralization is thought to be the main removal mechanism for experiments with a synthetic solution (Nidheesh et. al., 2017).

\section{Conclusions.}

Electrocoagulation system was optimized to remove arsenic from arsenic synthetic solution with an initial AS concentration of $100 \mathrm{ugL}^{-1}$ in terms of treatment time ( 7 minutes), applied current intensity (0.2 A) and iron electrode . Removal efficiency obtained was $90 \%$, achieving the Mexican $\left(25 \mathrm{ugL}^{-1}\right)$ and WHO $\left(10 \mathrm{ugL}^{-1}\right)$ Normativity Although when real groundwater was used, arsenic removal rate was lower than those obtained with As synthetic solution, Mexican's guideline for arsenic in drinking water was reached. Regardless residual arsenic concentration was slightly above WHO's guideline.

The results obtained in this research work show that electrocoagulation system can be considered an effective alternative to remove arsenic from water using low current intensities with a short treatment time. Besides, the optimal operating conditions determined in this work can be used as base to scale the electrocoagulation system in order to meet the water requirement of a small community with arsenic pollution problems.

\section{Acknowledgement}

The authors would like to express our sincere acknowledgement to the Group of work Mexico-Quebec (GTMQ) for funding given for the realization of the present research work. Also, acknowledgement is given to the Mexican National Council for Science and Technology (CONACYT) for the scholarship given to the first author. 


\section{References}

Ali, I., Al-Othman, Z. A., Alwarthan, A., Asim, M., \& Khan, T. A. (2014). Removal of arsenic species from water by batch and column operations on bagasse fly ash. Environmental Science and Pollution Research, 21(5), 3218-3229

Ali, I., Asim, M., \& Khan, T. A. (2013). Arsenite removal from water by electrocoagulation on zinc-zinc and copper-copper electrodes. International Journal of Environmental Science and Technology, 10(2), 377-384

Ali Imran, Al Arsh Basheer, X.Y. Mbianda, Alexander Burakov, Evgeny Galunin, Irina Burakova, Alina Mkrtchan, Alexey Tkachev, Vladimir Grachev.. 2019. Environment International, 127: 160-180

Ali, I., Gupta, V. K., Khan, T. A., \& Asim, M. (2012). Removal of arsenate from aqueous solution by electro-coagulation method using Al-Fe electrodes. Int. J. Electrochem. Sci., 7, 1898-1907.

Ali, I., Khan, T. A., \& Asim, M. (2011). Removal of arsenic from water by electrocoagulation and electrodialysis techniques. Separation \& Purification Reviews, 40(1), 25-42.

Ali, I., Khan, T. A., \& Asim, M. (2012). Removal of arsenate from groundwater by electrocoagulation method. Environmental Science and Pollution Research, 19(5), 16681676.

Amrose, S., Gadgil, A., Srinivasan, V., Kowolik, K., Muller, M., Huang, J., \& Kostecki, R. (2013). Arsenic removal from groundwater using iron electrocoagulation: effect of charge dosage rate. Journal of Environmental Science and Health, Part A, 48(9), 10191030 .

Asselin, M., Drogui, P. Benmoussa, H., \& Blais, J. F. (2008). Effectiveness of electrocoagulation process in removing organic compounds from slaughterhouse wastewater using monopolar and bipolar electrolytic cells.Chemosphere, 72(11), 17271733

Baig, S. A., Sheng, T., Hu, Y., Xu, J., \& Xu, X. (2015). Arsenic removal from natural water using low cost granulated adsorbents: a review. CLEAN-Soil, Air, Water, 43(1), 13-26.

Balasubramanian, N., Kojima, T., Basha, C. A., \& Srinivasakannan, C. (2009). Removal of arsenic from aqueous solution using electrocoagulation. Journal of hazardous materials, 167(1), 966-969.

Baş, D., \& Boyac1, İ. H. (2007). Modeling and optimization I: Usability of response surface methodology. Journal of Food Engineering, 78(3), 836-845.

Basheer Al arsh. 2018. Chemical Chiral pollution: Impact on the society and science and need of the regulation in 21st century. Chirality 30: 402-406.

Basheer Al Arsh. 2018b. New generation nano-adsorbent for the removal of emerging contaminants in water. Journal of Molecular Liquids, 261: 583-593. 
Basheer Al Arsh and Imran Ali. 2018. Stereoselective uptake and degradation of $( \pm)-0, p-$ DDD pesticide stereomers in water-sediment system. Chirality 30:1088-1095

Basu, A., Saha, D., Saha, R., Ghosh, T., \& Saha, B. (2014). A review on sources, toxicity and remediation technologies for removing arsenic from drinking water. Research on Chemical Intermediates, 40(2), 447-485.

Bhattacharya, P., Welch, A. H., Stollenwerk, K. G., McLaughlin, M. J., Bundschuh, J., \& Panaullah, G. (2007). Arsenic in the environment: biology and chemistry. Science of the total environment, 379(2), 109-120.

Camacho, L. M., Gutiérrez, M., Alarcón-Herrera, M. T., de Lourdes Villalba, M., \&.Deng, S. (2011). Occurrence and treatment of arsenic in groundwater and soil in northern Mexico and southwestern USA. Chemosphere, 83(3), 211-225.

Campbell, A., Becaria, A., Lahiri, D. K., Sharman, K., \& Bondy, S. C. (2004). Chronic exposure to aluminum in drinking water increases inflammatory parameters selectively in the brain. Journal of neuroscience research, 75(4), 565-572.

Can, B. Z., Boncukcuoglu, R., Yilmaz, A. E., \& Fil, B. A. (2014). Effect of some operational parameters on the arsenic removal by electrocoagulation using iron electrodes. Journal of Environmental Health Science and Engineering, 12(1), 1.

Choong, T. S., Chuah, T. G., Robiah, Y., Koay, F. G., \& Azni, I. (2007). Arsenic toxicity, health hazards and removal techniques from water: an overview. Desalination, 217(1), 139-166.

Del Ángel, P., Carreño, G., Nava, J. L., Martínez, M. T., \& Ortiz, J. (2014). Removal of arsenic and sulfates from an abandoned mine drainage by electrocoagulation. Influence of hydrodynamic and current density. Int J Electrochem Sci, 9, 710-719.

Demirbas, E., \& Kobya, M. (2017). Operating cost and treatment of metalworking fluid wastewater by chemical coagulation and electrocoagulation processes. Process Safety and Environmental Protection, 105, 79-90.

Demirbas, E., Kobya, M., Oncel, M. S., Şık, E., \& Goren, A. Y. (2019). Arsenite removal from groundwater in a batch electrocoagulation process: Optimization through response surface methodology. Separation Science and Technology, 54(5), 775-785.

Flores, O. J., Nava, J. L., Carreño, G., Elorza, E., \& Martínez, F. (2013). Arsenic removal from groundwater by electrocoagulation in a pre-pilot-scale continuous filter press reactor. Chemical Engineering Science, 97, 1-6.

García-Lara, A. M., \& Montero-Ocampo, C. (2010). Improvement of arsenic electroremoval from underground water by lowering the interference of other ions. Water, Air, and Soil Pollution, 205(1-4), 237-244.

García-Lara, A. M., Montero-Ocampo, C., Equihua-Guillen, F., Camporredondo-Saucedo, J. E., Servin-Castaneda, R., \& Muñiz-Valdes, C. R. (2014). Arsenic Removal from Natural 
Groundwater by Electrocoagulation Using Response Surface Methodology. Journal of Chemistry, 2014.

George, C. M., Inauen, J., Perin, J., Tighe, J., Hasan, K., \& Zheng, Y. (2017). Behavioral determinants of switching to arsenic-safe water wells: an analysis of a randomized controlled trial of health education interventions coupled with water arsenic testing. Health Education \& Behavior, 44(1), 92-102.

Gorny, J., Billon, G., Lesven, L., Dumoulin, D., Madé, B., \& Noiriel, C. (2015). Arsenic behavior in river sediments under redox gradient: a review. Science of the Total Environment, 505, 423-434.

Greenberg Arnold, E., \& Clesceri Lenore, S. (1992). Standard methods for the examination of water and wastewater.

Hansen, H. K., Nunez, P., Raboy, D., Schippacasse, I., \& Grandon, R. (2007). Electrocoagulation in wastewater containing arsenic: Comparing different process designs. Electrochimica Acta, 52(10), 3464-3470.

Hao, L., Wang, N., Wang, C., \& Li, G. (2018). Arsenic removal from water and river water by the combined adsorption-UF membrane process. Chemosphere, 202, 768-776.

Hubadillah, S. K., Othman, M. H. D., Ismail, A. F., Rahman, M. A., \& Jaafar, J. (2019). A low cost hydrophobic kaolin hollow fiber membrane (h-KHFM) for arsenic removal from aqueous solution via direct contact membrane distillation. Separation and Purification Technology, 214, 31-39.

Izah, S. C., \& Srivastav, A. L. (2015). Level of arsenic in potable water sources in Nigeria and their potential health impaets: A review. Journal of Environmental Treatment Techniques, 3(1), 15-24.

Jadhav, S. V., Bringas, E., Yadav, G. D., Rathod, V. K., Ortiz, I., \& Marathe, K. V. (2015). Arsenic and fluoride contaminated groundwaters: a review of current technologies for contaminants removal. Journal of Environmental Management, 162, 306-325.

Kaur, H., Kumar, R., Babu, J. N., \& Mittal, S. (2015). Advances in arsenic biosensor development-A comprehensive review. Biosensors and Bioelectronics, 63, 533-545.

Kobya, M., Demirbas, E., Gebologlu, U., Oncel, M. S., \& Yildirim, Y. (2013). Optimization of arsenic removal from drinking water by electrocoagulation batch process using response surface methodology. Desalination and Water Treatment, 51(34-36), 66766687.

Kumar, P. R., Chaudhari, S., Khilar, K. C., \& Mahajan, S. P. (2004). Removal of arsenic from water by electrocoagulation. Chemosphere, 55(9), 1245-1252.

Lakshmanan, D., Clifford, D. A., \& Samanta, G. (2010). Comparative study of arsenic removal by iron using electrocoagulation and chemical coagulation. Water research, 44(19), 5641-5652. 
Li, L., Li, J., Shao, C., Zhang, K., Yu, S., Gao, N., ... \& Yin, D. (2014). Arsenic removal in synthetic ground water using iron electrolysis. Separation and Purification Technology, 122, 225-230.

Maldonado Escalante, J. F., Meza Figueroa, A. G., Garcia Rico, L., Burguess, J. L., Lantz, R. C., Yañez Estrada, L., Martinez Cinco, M. A., Balderaz Cortéz, J. D. J., Mondaca Fernandez, I. Y Meza Montenegro, M. M. (2018). An integrated health risk assessment of indigenous children exposed to arsenic in Sonora, Mexico. Human and ecological risk assessment. https://doi.org/10.1080/10807039.2018.14449098.

Martinez-Villafane, J. F., Montero-Ocampo, C., \& Garcia-Lara, A. M. (2009), Energy and electrode consumption analysis of electrocoagulation for the removal of arsenic from underground water. Journal of hazardous materials, 172(2), 1617-1622.

Meza, M. M., Kopplin, M. J., Burgess, J. L., \& Gandolfi, A. J. (2004). Arsenic drinking water exposure and urinary excretion among adults in the Yaqui Valley, Sonora, Mexico. Environmental research, 96(2), 119-126.

Mohora, E., Rončević, S., Agbaba, J., Tubić, A., Mitić, M., Klašnja, M., \& Dalmacija, B. (2014). Removal of arsenic from groundwater rich in natural organic matter (NOM) by continuous electrocoagulation/flocculation (ECF). Separation and Purification Technology, 136, 150-156.

Mólgora, C. C., Domínguez, A. M., Avila, E. M., Drogui, P., \& Buelna, G. (2013). Removal of arsenic from drinking water: a comparative study between electrocoagulationmicrofiltration and chemical coagulation-microfiltration processes. Separation and Purification Technology, 118, 645-651.

Moussa, D. T., El-Naas, M. H., Nasser, M., \& Al-Marri, M. J. (2017). A comprehensive review of electrocoagulation for water treatment: Potentials and challenges. Journal of environmental management, 186, 24-41.

Nidheesh, P. V., \& Singh, T. A. (2017). Arsenic removal by electrocoagulation process: Recent trends and removal mechanism. Chemosphere, 181, 418-432.

NOM-127-SSA-1994. Salud ambiental, agua para uso y consumo humano-límites permisibles de calidad y tratamientos a que debe someterse el agua para su potabilización. Mexican secretariat of health (secretaría de salud Mexicana).

Oneel, M. S., Muhcu, A., Demirbas, E., \& Kobya, M. (2013). A comparative study of chemical precipitation and electrocoagulation for treatment of coal acid drainage wastewater. Journal of Environmental Chemical Engineering, 1(4), 989-995.

Pallier, V. (2008). Elimination de l'arsenic par coagulation floculation et électrocoagulation d'eaux faiblement minéralisées (Doctoral dissertation, Limoges).

Sabbatini, P., Yrazu, F., Rossi, F., Thern, G., Marajofsky, A., \& de Cortalezzi, M. F. (2010). Fabrication and characterization of iron oxide ceramic membranes for arsenic removal. Water research, 44(19), 5702-5712. 
Sahu, O., Mazumdar, B., \& Chaudhari, P. K. (2014). Treatment of wastewater by electrocoagulation: a review. Environmental science and pollution research,21(4), 23972413.

SEDESOL. (2013). Cátalago de localidades. Mexico. Recovered from: http://www.microrregiones.gob.mx/catloc/contenido.aspx?refnac $=260290202$

Şık, E., Demirbas, E., Goren, A. Y., Oncel, M. S., \& Kobya, M. (2017). Arsenite and arsenate removals from groundwater by electrocoagulation using iron ball anodes: Influence of operating parameters. Journal of water process engineering, 18, 83-91.

Song, P., Yang, Z., Xu, H., Huang, J., Yang, X., \& Wang, L. (2014). Investigation of influencing factors and mechanism of antimony and arsenic removal by electrocoagulation using Fe-Al electrodes. Industrial \& Engineering Chemistry Research, 53(33), 1291112919.

Vaclavikova, M., Gallios, G. P., Hredzak, S., \& Jakabsky, S. (2008). Removal of arsenic from water streams: an overview of available techniques. Clean Technologies and Environmental Policy, 10(1), 89-95.

Wan, W., Pepping, T. J., Banerji, T., Chaudhari, S., \& Giammar, D. E. (2011). Effects of water chemistry on arsenic removal from drinking water by electrocoagulation. Water research, 45(1), 384-392.

Wang, J. P., Chen, Y. Z., Ge, X. W., \& Yu, H. Q. (2007). Optimization of coagulationflocculation process for a paper-recycling wastewater treatment using response surface methodology. Colloids and Surfaces A. Physicochemical and Engineering Aspects, 302(1), 204-210.

World health organization. (2011). Arsenic in drinking water. Background document for development of WHO Guidelines for drinking water Quality. 24. $\mathrm{WHO} / \mathrm{SDE} / \mathrm{WSH} / 03.04 / 75 / \mathrm{Rev} / 1$

Zhang, T., Zhao, Y,, Bai, H., Wang, W., \& Zhang, Q. (2019). Enhanced arsenic removal from water and easy handling of the precipitate sludge by using $\mathrm{FeSO} 4$ with $\mathrm{CaCO} 3$ to $\mathrm{Ca}$ $(\mathrm{OH})$ 2. Chemosphere, 231, 134-139.

Zhao, X., Zhang, B., Liu, H., \& Qu, J. (2010). Removal of arsenite by simultaneous electrooxidation and electro-coagulation process. Journal of Hazardous materials, 184(1), 472476. 
Table 1: $\quad$ Experimental range and levels of independent process variables.

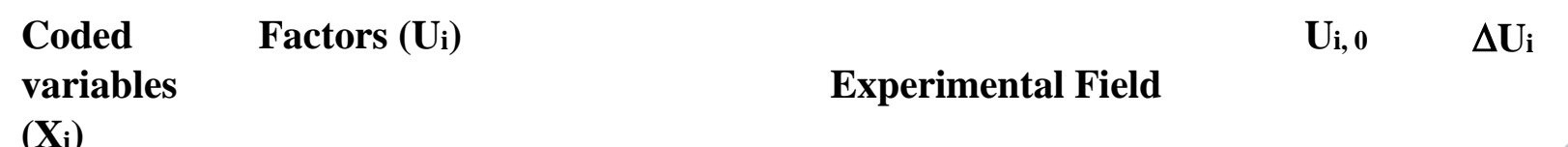

\begin{tabular}{llll}
\hline & $\begin{array}{c}\text { Min value } \\
(-\mathbf{1})\end{array}$ & $\begin{array}{c}\text { Max value } \\
(+\mathbf{1})\end{array}$ \\
\hline First set of FD experiments & $\mathrm{U}_{1}:$ Current intensity $(\mathrm{A})$ & 0.2 \\
\hline $\mathbf{X}_{\mathbf{1}}$ & $\mathrm{U}_{2}:$ Treatment time (min) & 2 \\
$\mathbf{X}_{\mathbf{2}}$ & $\mathrm{U}_{3}:$ Type of electrode & $\mathrm{Al}$ \\
$\mathbf{X} \mathbf{3}$ &
\end{tabular}

$\Delta \mathrm{Ui}$ : the step of the variation $((\Delta \mathrm{Ui}=\mathrm{Uimax}-\mathrm{Uimin}) / 2)$ to estimate axial values, which are calculated according these equations: Lower axial value $\left(\mathrm{U}_{\mathrm{i}, \alpha-}\right)=(\mathrm{Uimin})-\Delta \mathrm{Ui}^{*}(|\alpha|-1)$ and Upper axial value $\left(\mathrm{U}_{\mathrm{i}, \alpha^{+}}\right)=\operatorname{Uimax}+\Delta \mathrm{Ui}^{*}(|\alpha|-1)$ 
Table 2 : Factorial plan design and experimental results

\begin{tabular}{cccccccc}
\hline $\begin{array}{c}\text { Test } \\
\mathbf{S}\end{array}$ & \multicolumn{2}{c}{ Experimental design } & \multicolumn{2}{c}{ Experimental Plan } & $\begin{array}{c}\text { Experimenta } \\
\text { I Responses }\end{array}$ \\
\hline & $\mathbf{X}_{\mathbf{1}}$ & $\mathbf{X}_{\mathbf{2}}$ & $\mathbf{X}_{\mathbf{3}}$ & $\mathbf{U}_{\mathbf{1}}$ & $\mathbf{U}_{\mathbf{2}}$ & $\mathbf{U}_{3}$ & $\begin{array}{c}\text { As removal } \\
(\%)\end{array}$ \\
\hline 1 & -1 & -1 & -1 & $0.2 \mathrm{~A}$ & $2 \mathrm{~min}$ & $\mathrm{Fe}$ & 85.73 \\
2 & +1 & -1 & -1 & $0.5 \mathrm{~A}$ & $2 \mathrm{~min}$ & $\mathrm{Fe}$ & 42.47 \\
3 & -1 & +1 & -1 & $0.2 \mathrm{~A}$ & $10 \mathrm{~min}$ & $\mathrm{Fe}$ & 97.84 \\
4 & +1 & +1 & -1 & $0.5 \mathrm{~A}$ & $10 \mathrm{~min}$ & $\mathrm{Fe}$ & 87.22 \\
5 & -1 & -1 & +1 & $0.2 \mathrm{~A}$ & $2 \mathrm{~min}$ & $\mathrm{Al}$ & 96.97 \\
6 & +1 & -1 & +1 & $0.5 \mathrm{~A}$ & $2 \mathrm{~min}$ & $\mathrm{Al}$ & 18.26 \\
7 & -1 & +1 & +1 & $0.2 \mathrm{~A}$ & $10 \mathrm{~min}$ & $\mathrm{Al}$ & 97.54 \\
8 & +1 & +1 & +1 & $0.5 \mathrm{~A}$ & $10 \mathrm{~min}$ & $\mathrm{Al}$ & 97.74 \\
\hline
\end{tabular}


Table 3. Central composite design and experimental results

\begin{tabular}{|c|c|c|c|c|c|}
\hline \multirow[t]{2}{*}{ Tests } & \multicolumn{2}{|c|}{$\begin{array}{c}\text { Experimental } \\
\text { design }\end{array}$} & \multicolumn{2}{|c|}{$\begin{array}{c}\text { Experimental } \\
\text { plan }\end{array}$} & \multirow{2}{*}{$\begin{array}{c}\begin{array}{c}\text { Experimental } \\
\text { Responses }\end{array} \\
\text { Removal As (\%) }\end{array}$} \\
\hline & $\mathbf{X}_{1}$ & $\mathbf{X}_{2}$ & $\begin{array}{l}\mathrm{U}_{1} \\
(\mathrm{~A})\end{array}$ & $\begin{array}{c}\mathbf{U}_{2} \\
(\mathrm{~min})\end{array}$ & \\
\hline \multicolumn{6}{|c|}{ For iron electrode $\left(\mathbf{U}_{1}\right)$} \\
\hline 9 & $-\overline{41}$ & 0 & 0.14 & 6 & 99.79 \\
\hline 10 & 1.41 & 0 & 0.56 & 6 & \\
\hline 11 & 0 & -1.41 & 0.35 & 0.34 & 79 \\
\hline 12 & 0 & 1.41 & 0.35 & 1.0 & 87.45 \\
\hline 13 & 0 & 0 & 0.35 & & 60.91 \\
\hline 14 & 0 & 0 & 0.35 & 6 & 63.14 \\
\hline 15 & 0 & 0 & 0 & 6 & 63.06 \\
\hline 16 & 0 & & 0.35 & 6 & 54.18 \\
\hline 17 & 0 & & 0.35 & 6 & 46.22 \\
\hline \multicolumn{6}{|c|}{ For Aluminum electrode $\left(\mathrm{U}_{2}\right)$} \\
\hline & - & 0 & 0.14 & 6 & 20.40 \\
\hline & 1.41 & 0 & 0.56 & 6 & 52.43 \\
\hline 20 & 0 & -1.41 & 0.35 & 0.34 & 26.51 \\
\hline 21 & 0 & 1.41 & 0.35 & 11.66 & 95.63 \\
\hline 22 & 0 & 0 & 0.35 & 6 & 61.74 \\
\hline 23 & 0 & 0 & 0.35 & 6 & 69.58 \\
\hline 24 & 0 & 0 & 0.35 & 6 & 70.63 \\
\hline
\end{tabular}




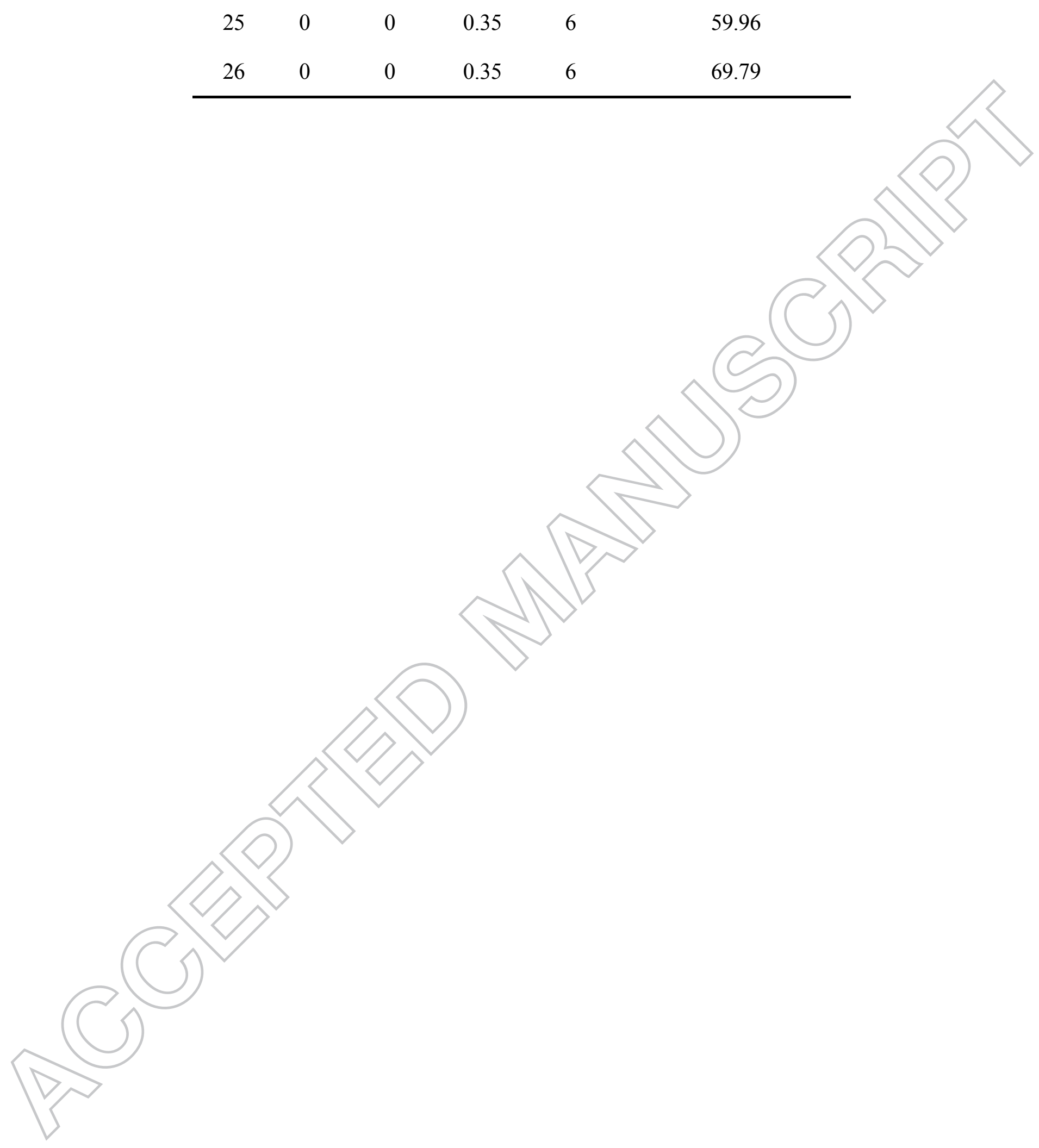


Table 4: Arsenic residual concentration $(\mu \mathrm{g} / \mathrm{L})$ in function of iron dose and charge loading $(\mathrm{C} / \mathrm{L})$ for experiments with real ground water.

\begin{tabular}{c|c|c|c}
\hline Time & $\begin{array}{c}\text { Charge } \\
\text { loading } \\
(\mathbf{m i n})\end{array}$ & $\begin{array}{c}\text { Iron dose } \\
(\mathbf{m})\end{array}$ & $\begin{array}{c}\text { Arsenic } \\
\text { concentration } \\
(\boldsymbol{\mu g} / \mathbf{L})\end{array}$ \\
\hline \multicolumn{4}{c}{ Real ground water } \\
\hline 0 & 0 & 0 & 80.16 \\
7.29 & 43.47 & 12.58 & 50.9 \\
15 & 90 & 25.88 & 48.52 \\
30 & 180 & 51.76 & 11.86 \\
\hline \multicolumn{4}{c}{ Synthetic solution } \\
\hline 0 & 0 & 0 & 91.15 \\
7.29 & 43.47 & 12.58 & 2.5 \\
\hline
\end{tabular}




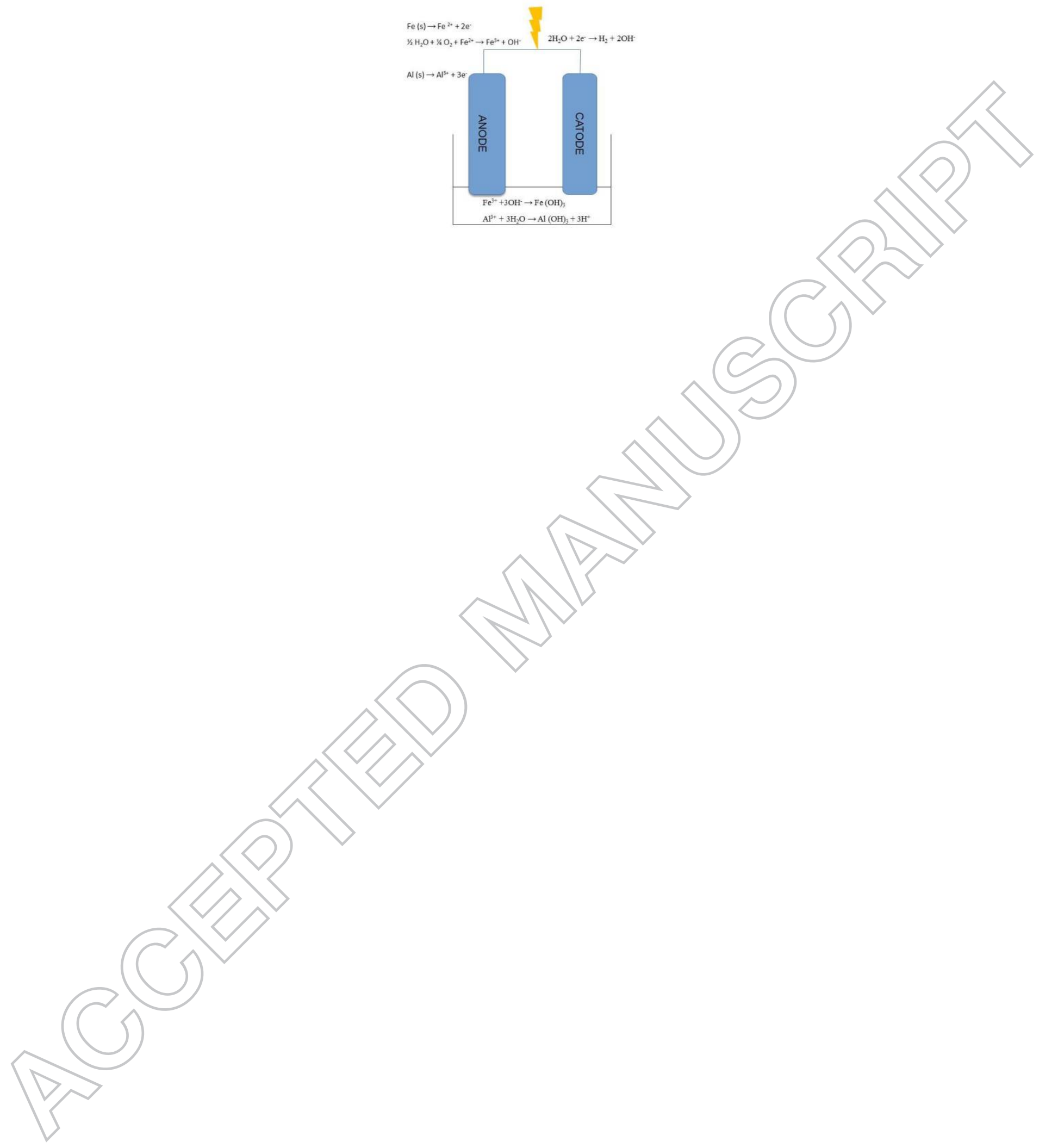




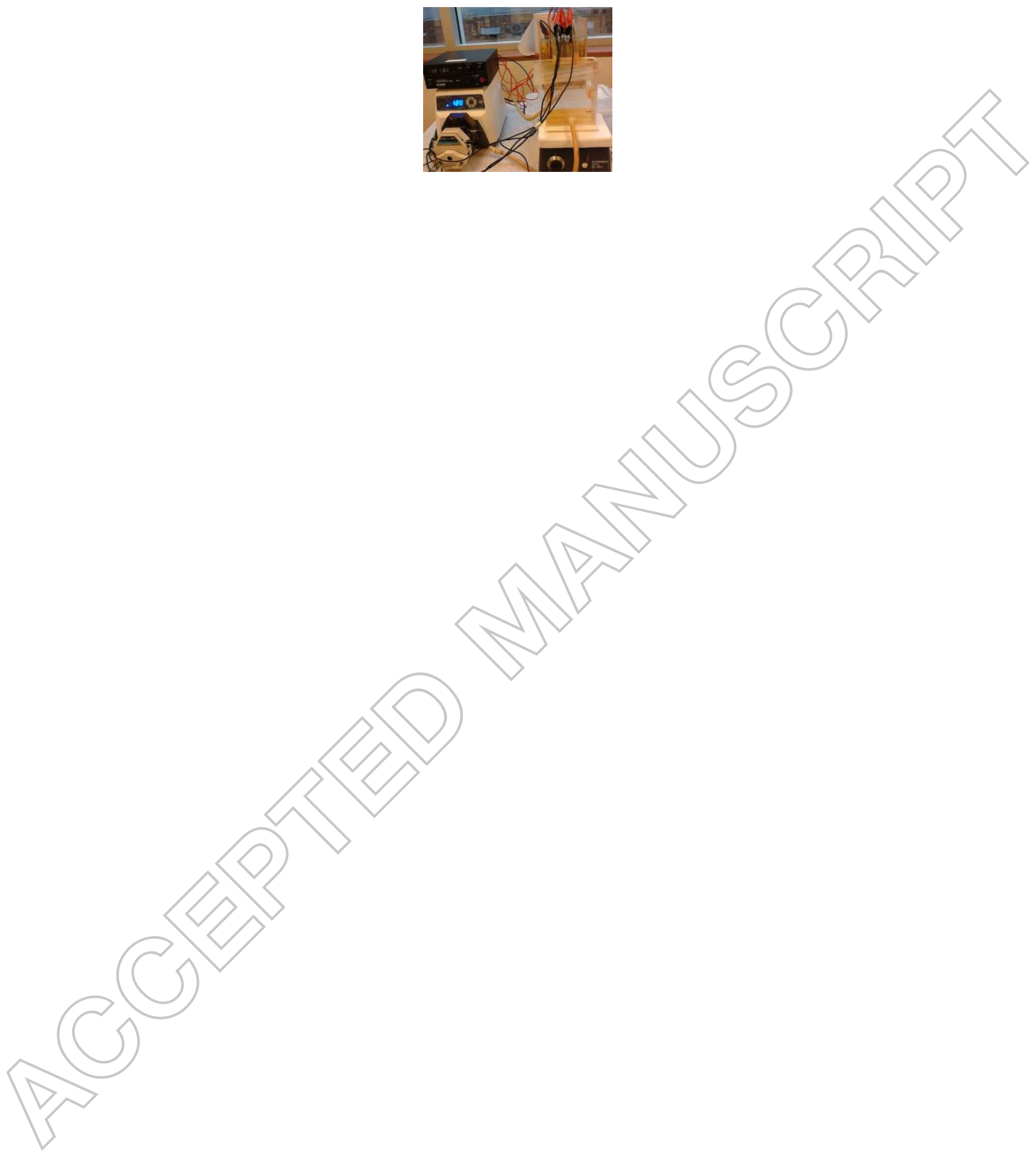




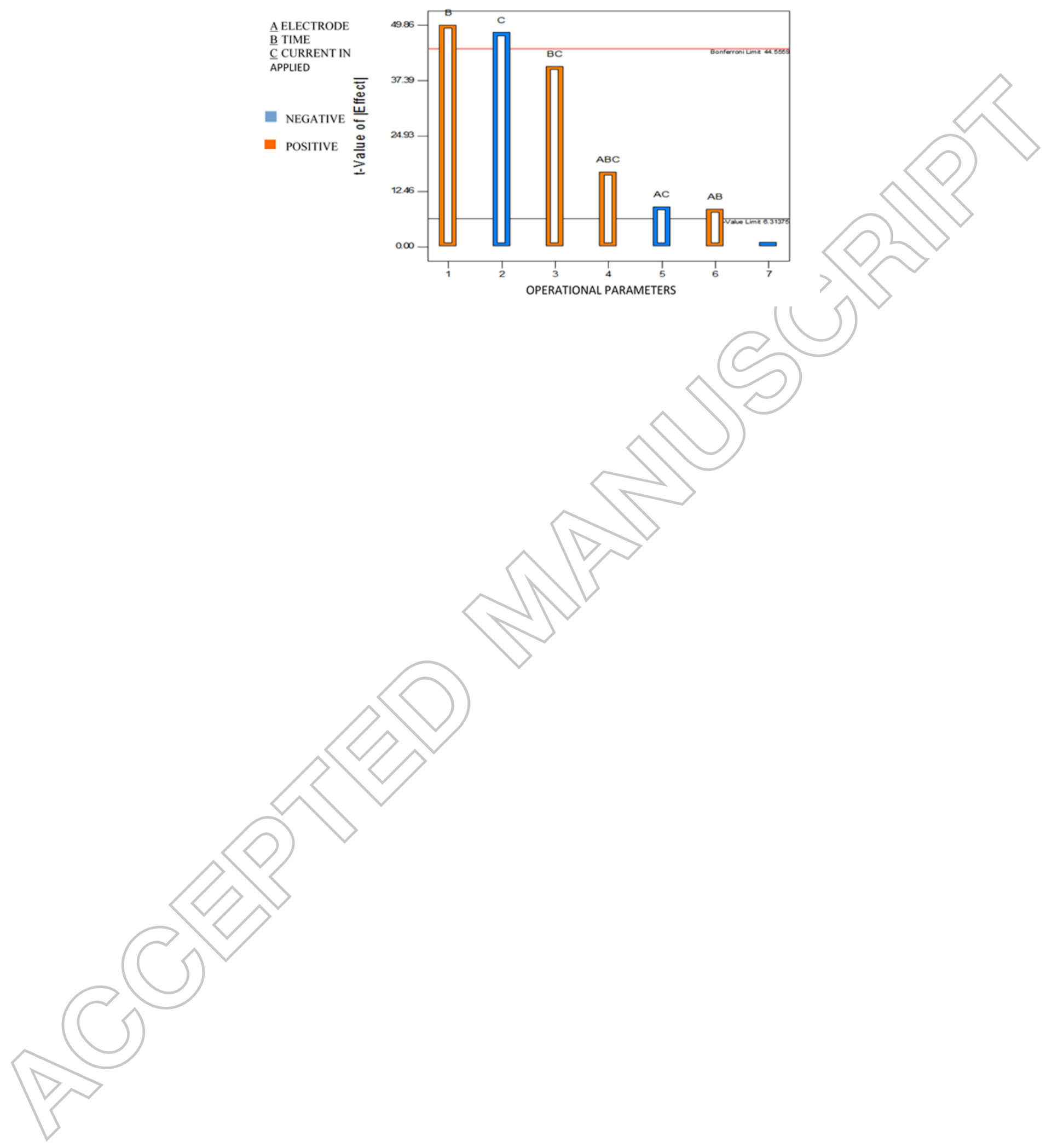



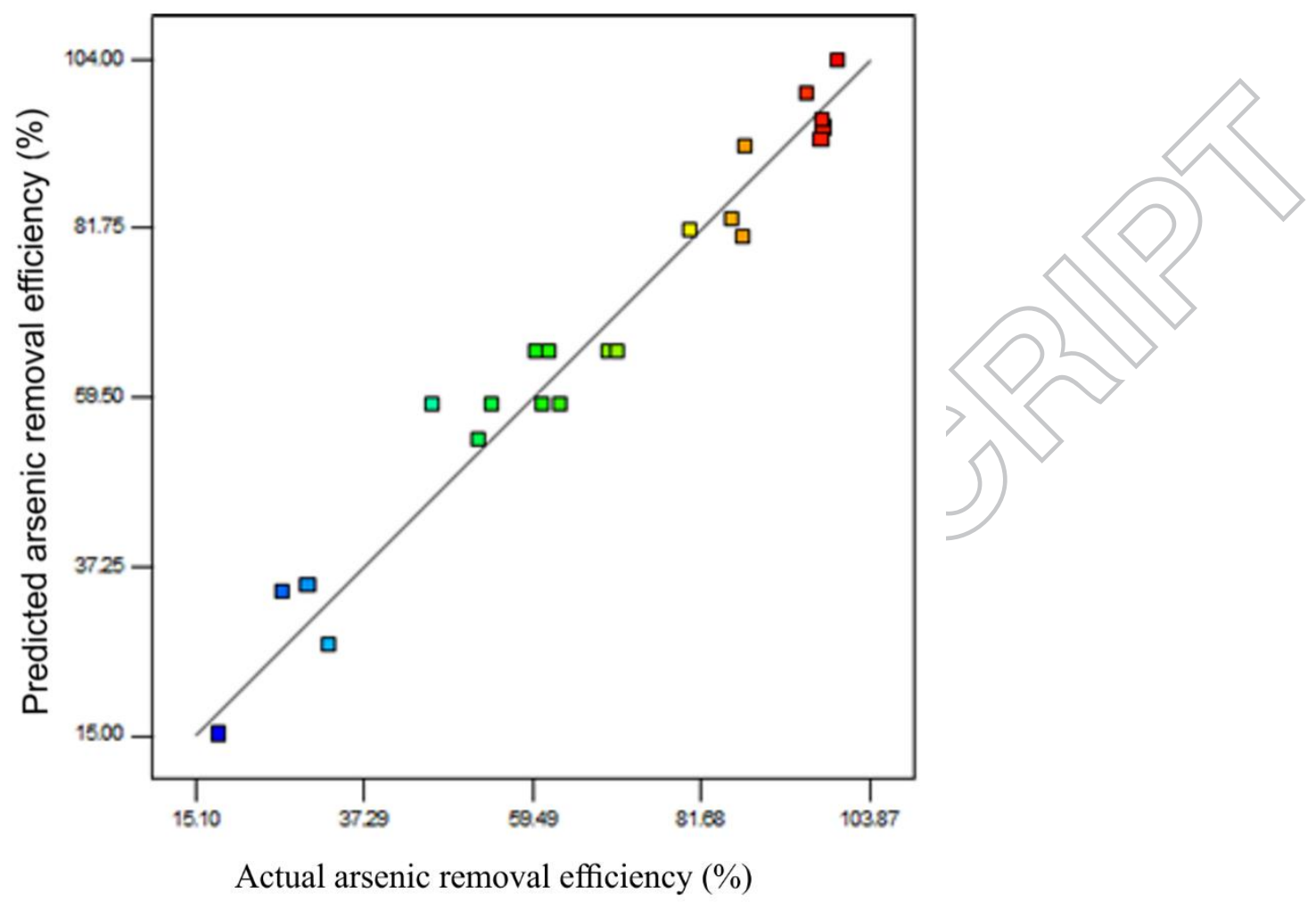

Actual arsenic removal efficiency (\%) 


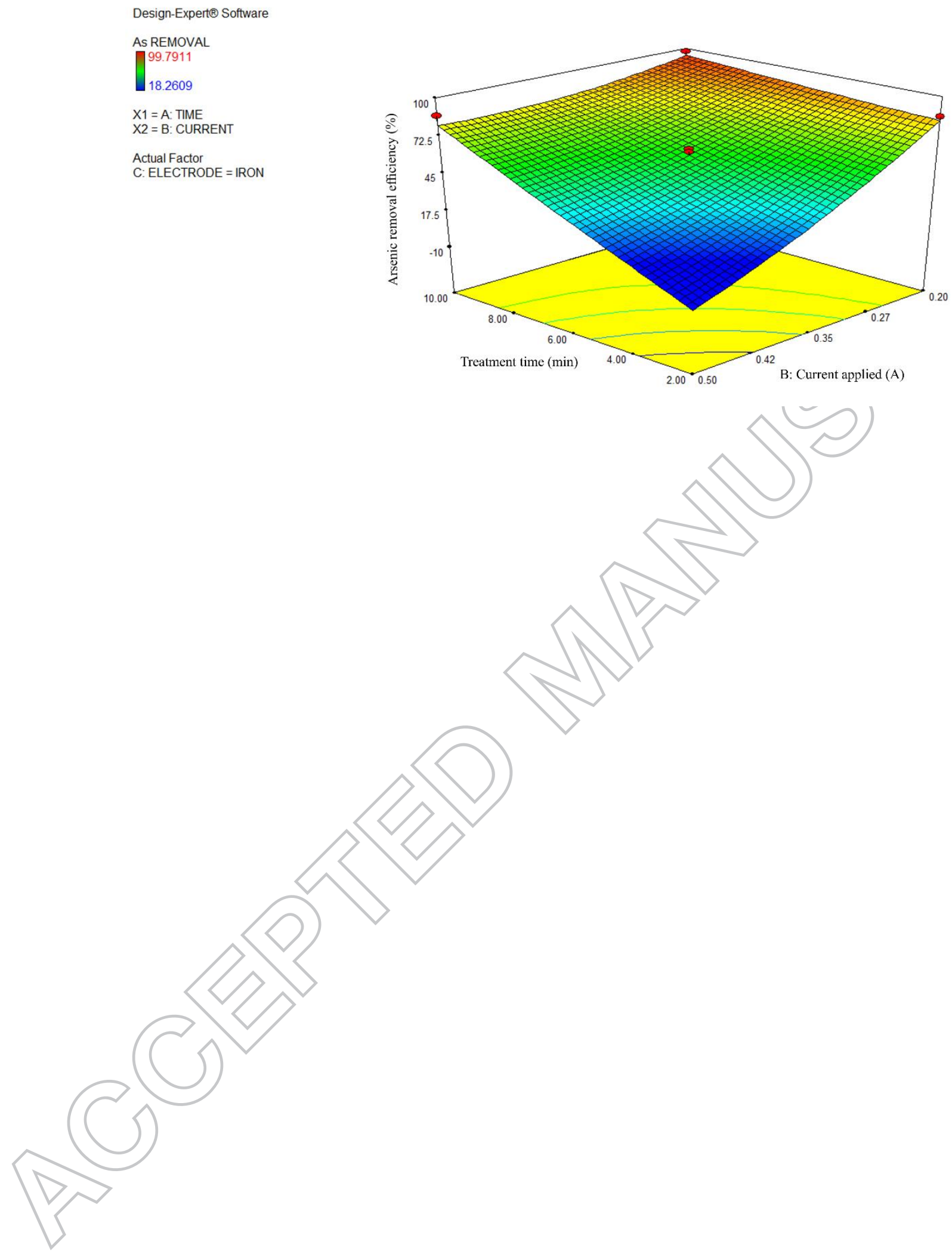



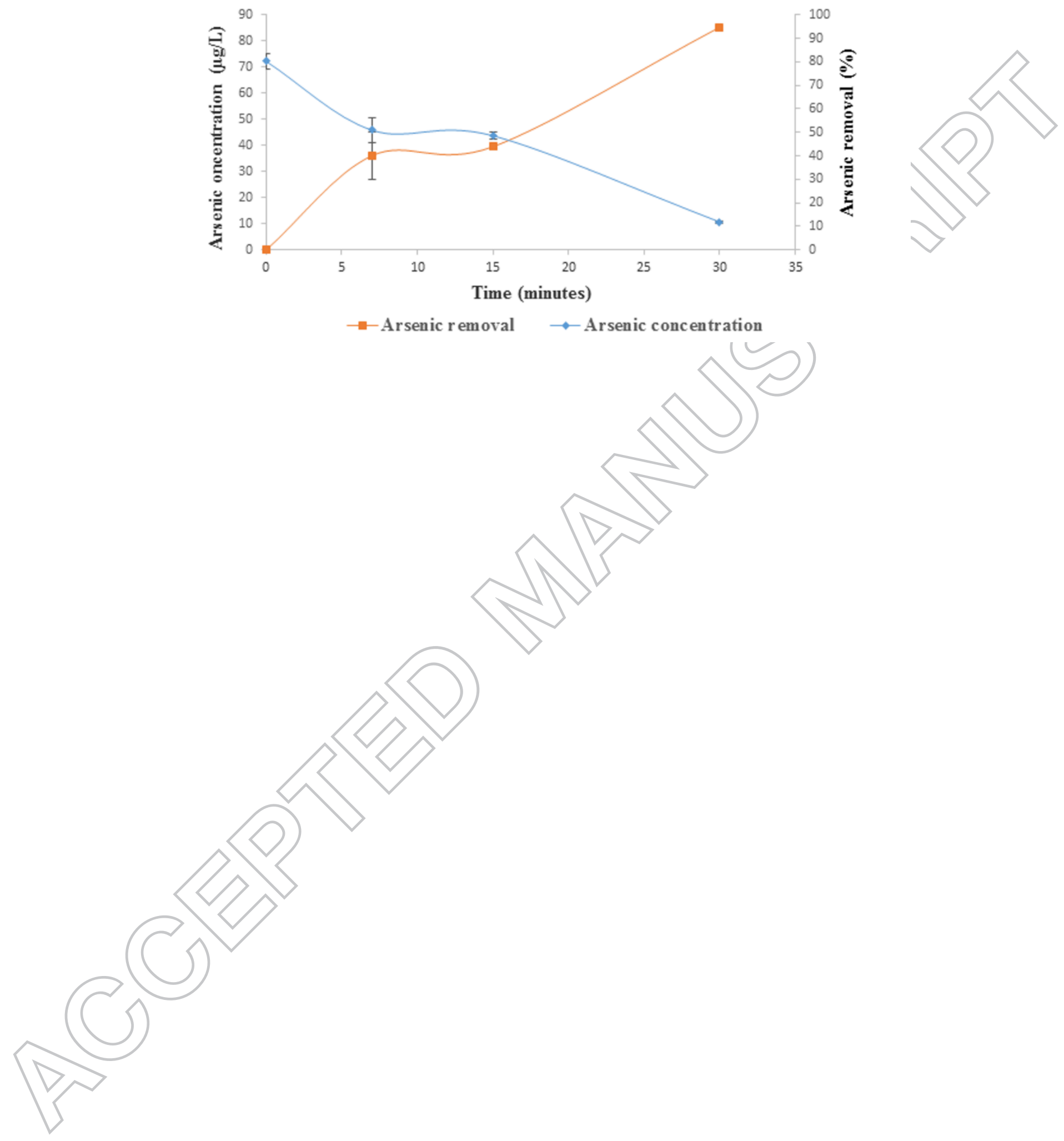

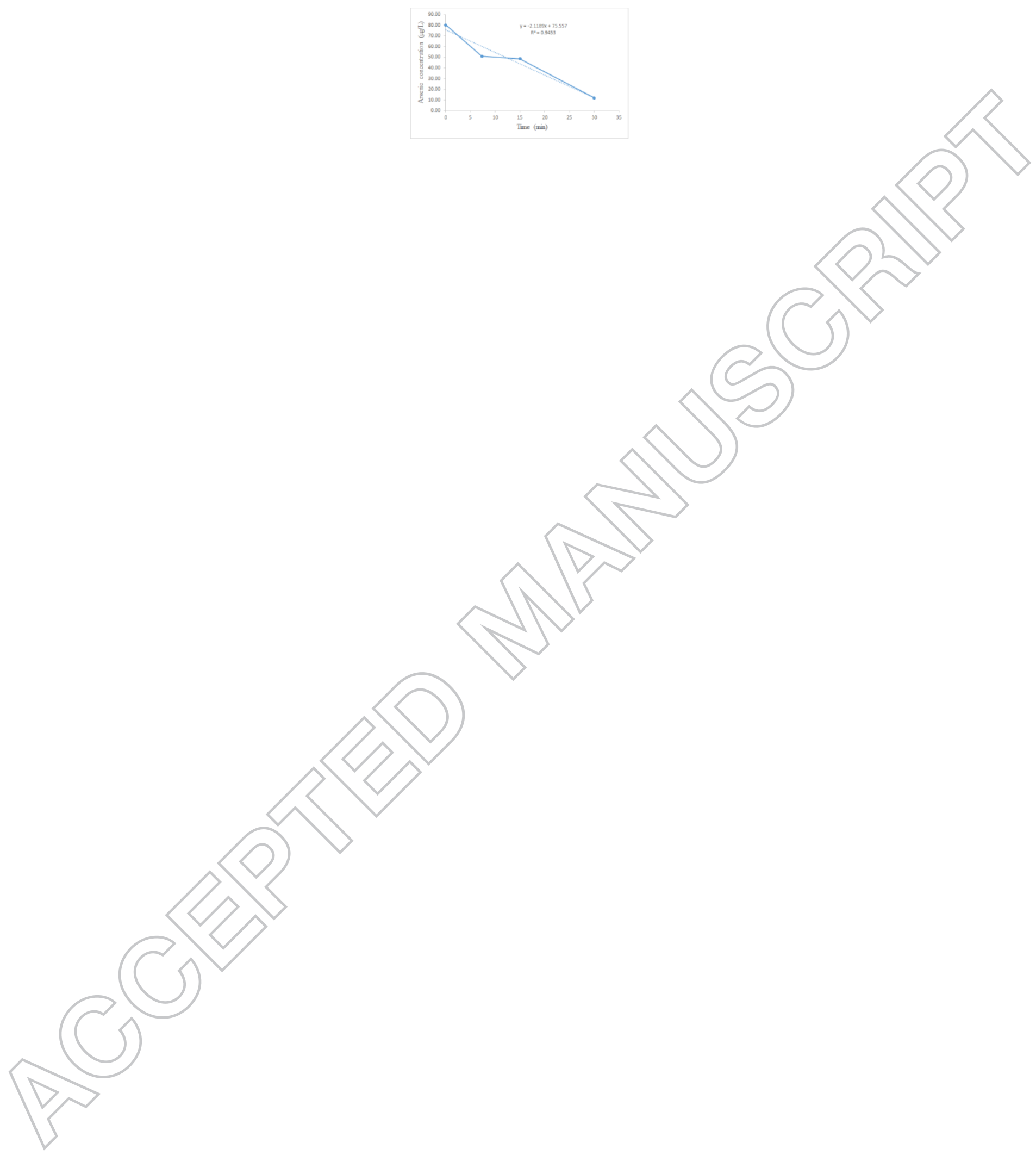

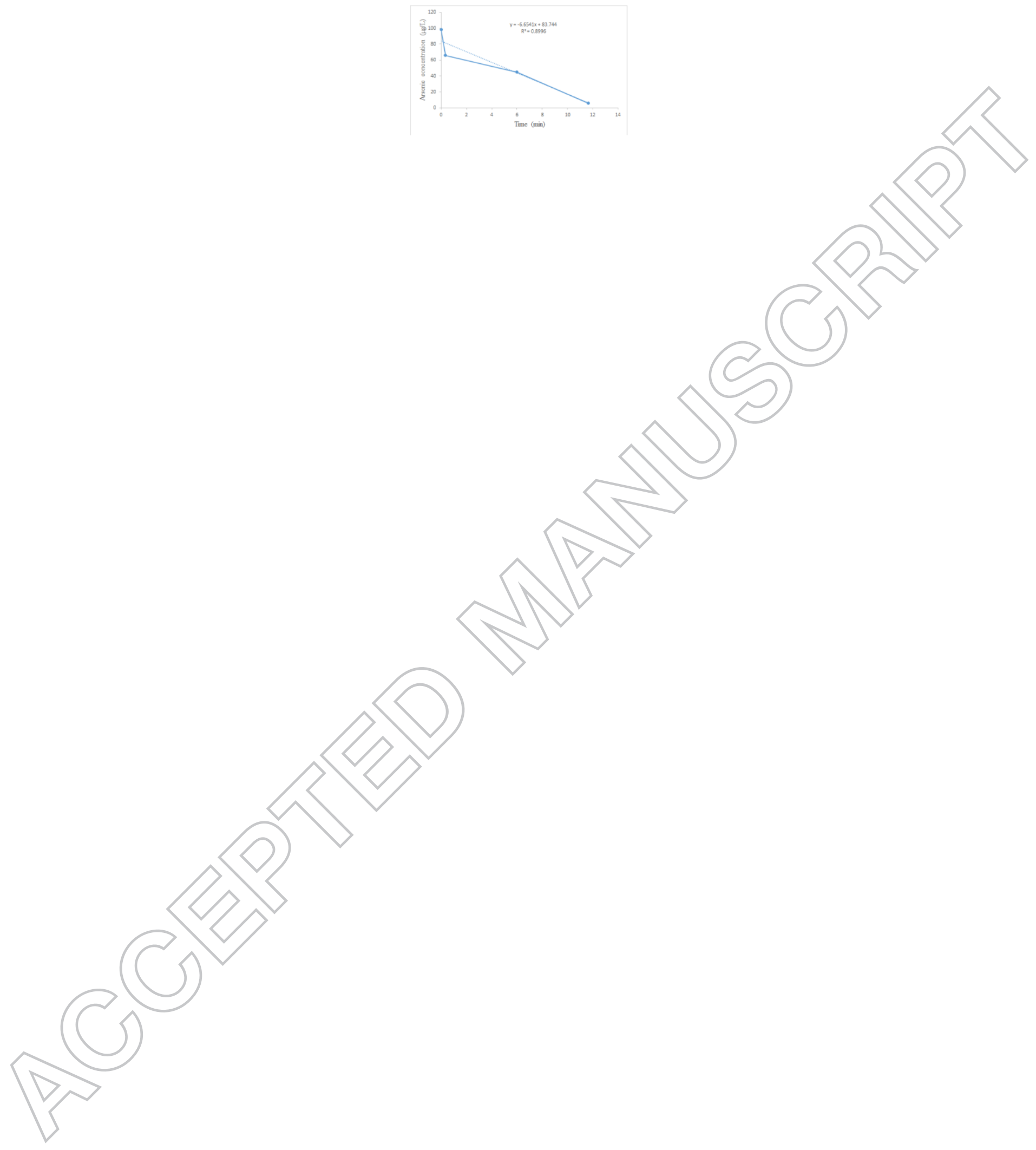